\title{
Comparison of Anoxic Ammonia Removal Using Granulated Nanostructured Oxyhydroxides of Fe with Seed Biomass From Different Eco-System
}

\author{
B.Kaavya Shree ${ }^{1}$, G.Varna ${ }^{2}$, M.Pooja ${ }^{3}$, P.C.Sabumon ${ }^{4}$ \\ ${ }^{1,23}$ School of Civil Engineering, Final Year Student, Vellore Institute of Technology (VIT), \\ Chennai, Tamilnadu, India \\ ${ }^{4}$ School of Civil Engineering, Professor, Vellore Institute of Technology (VIT), Chennai, Tamilnadu, India \\ * Corresponding author: Phone: +91-44-3993 1048, Fax: +91- 44- 39932555
}

E-mail: pcsabumon@ vit.ac.in

\begin{abstract}
Removal of ammonium in anoxic conditions with the aid of granulated nanostructured oxyhydroxides of $\mathrm{Fe}(\mathrm{GNOF})$ was investigated in sequential batch reactors for biomass with different eco-systems as the source.GNOF was synthesized using a simple template-assisted one-pot technique. The removal of $\mathrm{NH}_{4}{ }^{+}$occurs via a unique short-circuited pathway mediated by a mixed culture of microbes that involves oxidation of ammonium which is coupled to the reduction of $\mathrm{Fe}^{3+}$ along with the formation of $\mathrm{N}_{2}, \mathrm{NO}_{2}^{-}$, and $\mathrm{NO}_{3}^{-}$. Further, the reduced $\mathrm{Fe}^{2+}$ is oxidized back to $\mathrm{Fe}^{3+}$ and hence reducing the amount of GNOF needed to be added to the reactors to ensure the process sustenance. Anoxic removal of $\mathrm{NH}_{4}^{+}$was confirmed from the Enrichment of culture results for 86 days using both aerobic and anaerobic sludge to draw a comparison among the two for their potential to serve as seed biomass. The percentage of removal of $\mathrm{NH}_{4}^{+}$was observed to be $94.65 \%$ and $95.07 \%$ for aerobic and anaerobic sludge, respectively, indicating both the seed sludges could be used for developing the process. This process is advantageous over the conventional techniques used for $\mathrm{NH}_{4}{ }^{+}$removal as it is more environmentfriendly and economical as less sludge needs to be handled and no aeration is required.
\end{abstract}

Keywords-Anoxic ammonia removal, Granulated nanoscale oxyhydroxides of $\mathrm{Fe}(\mathrm{GNOF})$, Sequencing batch reactor (SBR), Oxidation-reduction potential(ORP), Enrichment of biomass

\section{INTRODUCTION}

Accumulation of ammonium ions $\left(\mathrm{NH}_{4}^{+}\right)$in water bodies can have a detrimental effect on the aquatic flora and fauna thriving in them, besides leading to eutrophication and depletion of oxygen. Hence, the removal of $\mathrm{NH}_{4}{ }^{+}$from wastewater is of immense significance to curb water pollution that is prevalent in many parts of the world today. The process of anaerobic ammonium oxidation(Anammox) is a promising and sustainable alternative to the conventional nitrification-denitrification technique used for the removal of $\mathrm{NH}_{4}^{+}$as the Anammox process can lower the oxygen demand by $64 \%$, biomass yield by $80-90 \%$ and exogenous carbon required by $100 \%$ resulting in reduced operational costs in comparison to the conventional removal technique used [1]. Employing a biological process such as this is advantageous over physicochemical techniques such as ammonia air stripping, breakpoint chlorination, selected ion-exchange etc., as the former is ecologically sound and renders minimum harm to the environment.

In the Anammox process, $\mathrm{NO}_{2}{ }^{-}$acts as the electron acceptor to oxidize $\mathrm{NH}_{4}{ }^{+}$to $\mathrm{N}_{2}$ gas facilitated by a bacteria belonging to the Planctomycetes order[2]. It has been reported that the impact of metal ions such as $\mathrm{Fe}^{2+}$ and $\mathrm{Fe}^{3+}$ on the growth of Anammox bacteria is prominent due to the presence of $\mathrm{Fe}$ in anammoxosome-an intracytoplasmic compartment bounded by a membrane that facilitates the oxidation of $\mathrm{NH}_{4}{ }^{+}-\mathrm{N}$. It has also been observed that $\mathrm{Fe}^{3+}$ serves as the electron Vol. 4 (5), November 2020, www.ijirase.com acceptor in place of oxygen and prevents the accumulation of $\mathrm{NH}_{4}^{+}$through the coupling of $\mathrm{NH}_{4}^{+}$oxidation and reduction of $\mathrm{Fe}^{3+}$ to $\mathrm{Fe}^{2+}$ in wetland soil [3], freshwater sediments[4], lake sediments [5] paddy soil [6], and activated sludge [7] as in an anaerobic environment as dissimilatory reducing bacteria obtain energy from $\mathrm{NH}_{4}{ }^{+}$ ions[8]. This phenomenon occurs due to ferric ion and oxygen's similar electrochemical properties with the standard redox potential of ferric ion being $770 \mathrm{mV}$ and that of oxygen being $816 \mathrm{mV}$ or due to appropriate enzyme systems. This results in another pathway through which the anoxic removal of $\mathrm{NH}_{4}^{+}$is accomplished [9]. As the Anammox bacteria exhibits a slow growth rate with the doubling time being 7-22 days and high sensitivity to environmental conditions, demand for a faster and feasible process to remove $\mathrm{NH}_{4}{ }^{+}$arises [10].

Iron is a commonly available metal and has a high redox potential. Literature indicates that metal oxides have a vital role in the alternative anoxic process for the oxidation of $\mathrm{NH}_{4}{ }^{+}$. The iron reduction process through iron respiration was identified widely due to the high availability of ferric oxides/hydroxides [11]. When conditions of low redox potential prevail, a shift in thermodynamic equilibrium can be observed and consequently, $\mathrm{Fe}^{3+}$ is reduced to $\mathrm{Fe}^{2+}$ and this could be coupled to the oxidation of $\mathrm{NH}_{4}^{+}$. The end products can be $\mathrm{N}_{2}, \mathrm{~N}_{2} \mathrm{O}, \mathrm{NO}, \mathrm{NO}_{3}^{-}$or $\mathrm{NO}_{2}$ [12]. It was observed that $\mathrm{Fe}^{2+}$ could be oxidized to $\mathrm{FeO}_{x}$ again along with the reduction of $\mathrm{NO}_{3}{ }^{-}$or $\mathrm{NO}_{2}{ }^{-}$. 
Interestingly, iron-oxidizing bacteria have been reported to mediate the $\mathrm{Fe}^{2+}$ oxidation to $\mathrm{Fe}^{3+}$ using $\mathrm{NO}_{3}^{-}$or $\mathrm{NO}_{2}^{-}$as electron acceptors [13]. Bacteria responsible for the anoxic removal $\mathrm{NH}_{4}^{+}$demand an anaerobic environment as observed by Truong et al. [14] for efficient activity apart from being highly dependent on temperature, $\mathrm{pH}$, and organic presence matter. According to the literature, $\mathrm{Fe}^{2+} / \mathrm{Fe}^{3+}$ can enhance bacteria activity that can remove $\mathrm{NH}_{4}{ }^{+}$by providing an appropriate anoxic environment [1516]. The following reactions reveal the pathway through which $\mathrm{NH}_{4}{ }^{+}$is oxidized and that oxyhydroxides of Fe can be of vital significance in the anoxic removal of $\mathrm{NH}_{4}{ }^{+}$[17].

$$
\begin{aligned}
& 6 \mathrm{FeOOH}+2 \mathrm{NH}_{4}{ }^{+}+10 \mathrm{H}^{+} \rightarrow 6 \mathrm{Fe}^{2+}+\mathrm{N}_{2}+12 \mathrm{H}_{2} \mathrm{O} ; \Delta \mathrm{G} \\
& =-233 \mathrm{~kJ} / \mathrm{mol} \\
& 9 \mathrm{FeOOH}+\mathrm{NH}_{4}^{+}+19 \mathrm{H}^{+} \rightarrow 9 \mathrm{Fe}^{2+}+\mathrm{NO}_{2}^{-}+16 \mathrm{H}_{2} \mathrm{O} ; \Delta \mathrm{G} \\
& =-71 \mathrm{~kJ} / \mathrm{mol} \\
& 11 \mathrm{FeOOH}+\mathrm{NH}_{4}^{+}+23 \mathrm{H}^{+} \\
& \rightarrow 11 \mathrm{Fe}^{2+}+\mathrm{NO}_{3}^{-}+19 \mathrm{H}_{2} \mathrm{O} ; \mathrm{\Delta G} \\
& =-38 \mathrm{~kJ} / \mathrm{mol} \\
& 9 \mathrm{Fe}^{2+}+2 \mathrm{NO}_{2}{ }^{-}+14 \mathrm{H}_{2} \mathrm{O} \rightarrow 9 \mathrm{FeOOH}+\mathrm{N}_{2}+19 \mathrm{H}^{+} ; \mathrm{G} \\
& =-287 \mathrm{~kJ} / \mathrm{mol} \\
& \rightarrow 11 \mathrm{FeOOH}+\mathrm{N}_{2}+21 \mathrm{H}^{+} ; \Delta \mathrm{G} \\
& =-483 \mathrm{~kJ} / \mathrm{mol}(5)
\end{aligned}
$$

Studies on the use of nanoscale oxides of Fe for anaerobic removal of $\mathrm{NH}_{4}{ }^{+}$and comparison based on the effect of the type of biomass used for the anoxic removal of $\mathrm{NH}_{4}^{+}$is limited. Therefore, the objective of the work is to study the feasibility of anoxic ammonium oxidation in the presence of granulated nanoscaleoxyhydroxides of iron(GNOF) for biomass obtained from two different ecological systems.Granulated oxyhydroxides of Fe (GNOF) is chosen for use as it can be separated from treated water with ease when used in a suspended growth system.

The major limitation of the anammox process is the extremely slow growth rate of the culture[18] and hence SBR is used in this study as it enables high biomass

Vol. 4 (5), November 2020, www.ijirase.com retention[19]. Previous studies identified that any sludge, aerobic/anaerobic/mixed activated sludge could be used as the seed biomass to enrich bacteria for the anammox process[20-21]. Hence, Enrichment of culture was done using two different seed biomass, aerobic activated sludge obtained from VIT's sewage treatment plant and anaerobic sludge from the anaerobic sludge digestor of Perungudi's sewage treatment plant, Chennai, India. This study also aims to compare the effect of the seed biomass used on the removal of $\mathrm{NH}_{4}^{+}$using sequencing batch reactors(SBR) at a laboratory scale for a period of 86 days in the presence of GNOF.

\section{MATERIALS AND METHOD}

\section{A. Experimental plan}

The study involved the following procedures: (a) Synthesis of GNOF by a template-assisted one-pot method

(b) Collection of seed biomass (c) Enrichment of seed biomass and operation of SBR with a variation in cycle time Synthesis of GNOF was done by a simple process, which is a template-assisted one-pot method as reported by Swathi et al. [17]. Aerobic activated sludge from the domestic sewage treatment plant at VIT and anaerobic sludge from the sludge digester of the sewage treatment plant at Perungudi, Chennai, India, collected and used as seed biomass for the removal of ammonia through a pathway mediated by microbes. Feasibility studies were performed using serum bottles to check if there is the removal of ammonia in an anaerobic condition in the presence of GNOF. After confirming the feasibility of the process, Enrichment of the culture was done to ensure the biomass's acclimatization to the needs of the experiment. This was carried out for 15 cycles over a period of 86 days in SBR and various parameters such as $\mathrm{pH}, \mathrm{ORP}$, amount of $\mathrm{NO}_{3}{ }^{-}, \mathrm{NO}_{2}{ }^{-}, \mathrm{NH}_{4}{ }^{+}$, and COD were monitored in each cycle. The input concentration of $\mathrm{NH}_{4}{ }^{+}$remained at $80 \mathrm{mg} / \mathrm{L}$ throughout the study while the cycle time was reduced from 3 days to 1 day. The time for feeding, settling and decanting was less than $2 \mathrm{~h}$.

\section{B. Reagents and mineral media}

Procurement of the chemicals was from Thomas Baker (India) Pvt. Ltd. Chitosan flakes were procured from Pelican Laboratories, Kerala, India. The reagents used for this study were all of analytical grade (AR).

Preparation of mineral media and trace elements solution was done as reported by Sabumon [22] and the mineral media composition (in $\mathrm{g}$ )is as follows: $\mathrm{KHCO}_{3}-0.7372$; $\mathrm{K}_{2} \mathrm{HPO}_{4}-0.1717 ; \mathrm{CaCl}_{2}-0.3 ; \mathrm{MgSO}_{4} .7 \mathrm{H} 20-0.2 ; \mathrm{FeCl}_{2}-$ 0.00464 ; EDTA-0.00625; dissolved in distilled water of 1 
L. $1 \mathrm{~mL}$ of trace elements solution is added for $1 \mathrm{~L}$ of the mineral media.

\section{C. $\quad$ Seed biomass for Enrichment of the culture}

Activated sludge was collected from VIT, Chennai, sewage treatment plant and anaerobic sludge from the sludge digester of the sewage treatment plant at Perungudi, Chennai, India, in clean plastic containers to their maximum capacity. The containers were sealed correctly and no headspace was given for air. The containers were transported to the lab immediately and stored under anoxic conditions.

\section{Enrichment studies}

Enrichment of biomass for anoxic removal of $\mathrm{NH}_{4}{ }^{+}$was done using both the seed sludges collected in two glass reagent bottles of $2 \mathrm{~L}$ capacity each. $800 \mathrm{~mL}$ of each type of biomass was added to the bottles. The amount of GNOF added was $30 \mathrm{~g}$ in each bottle. The $\mathrm{NH}_{4}{ }^{+}$concentration added was $80 \mathrm{mg} / \mathrm{L}$ and no COD was added. After the addition of sludge, GNOF, and $\mathrm{NH}_{4}^{+}$, the bottles were completely filled with mineral media which was purged with pure $\mathrm{N}_{2}$ gas for 10 minutes. Rubber corks fitted with glass tubes were used to close the bottles tightly and to enable the escape of gaseous products through a water seal. The reactor operated in anoxic condition at room temperature $\left(30-34{ }^{\circ} \mathrm{C}\right)$ in sequencing batch mode. These bottles were also covered with black polythene sheets and manual shaking was done at regular intervals to facilitate mixing. There were five phases in the SBR operation which included fresh feed filling(fill),reaction between biomass and feed(react),biomass settling(settle),treated water decantation(decant) and idle position(idle). This operation was performed with a cycle time of 3 days over a span of 58 days and then the cycle time was decreased to 1 day from the 59th day. Samples from the reactors were analyzed for $\mathrm{pH}, \mathrm{ORP}, \mathrm{NO}_{3}{ }^{-}, \mathrm{NO}_{2}{ }^{-}, \mathrm{NH}_{4}{ }^{+}$and $\mathrm{COD}$ at the end of each cyle.

\section{E. Techniques for analyses}

All analyses for various parameters were performed according to Standard Methods for the examination of water and wastewater [23].pH was measured using a $\mathrm{pH}$ meter $(\mathrm{pH}$ 720) of WTW inoLab made in Germany and ORP was measured using a microORP electrode. To measure the concentration of $\mathrm{NO}_{3}{ }^{-}, \mathrm{NO}_{2}{ }^{-}, \mathrm{NH}_{4}{ }^{+}, \mathrm{UV}$ spectrophotometer (ThermoScientific) was used after appropriately diluting the samples. To analyze COD, Dichromate method was used.Triple distilled water was used for the dilution of samples and preparation of reagents.

\section{RESULTS AND DISCUSSION}

Based on the removal of $\mathrm{NH}_{4}{ }^{+}$ions observed in the feasibility studies, Enrichment of biomass was done. The results obtained from the enrichment phase confirm that anoxic removal of ammonium occurs in the presence of GNOF. Various parameters observed during the Enrichment of biomass to facilitate the removal of ammonium are given in the figures. In the figures, phase I indicates a cycle time of 3 days, whereas phase II represents a cycle time of 1 day. The study's final $\mathrm{pH}$ values remained in the range of 7-8 which implies that simultaneous nitrification-denitrification occurs.It also indicates that the removal of ammonium is not due to volatilization or precipitation [17].ORP values were in the range of -100 to $-150 \mathrm{mV}$, indicating the absence of oxygen in the reactors and thereby ensuring that the removal of $\mathrm{NH}_{4}{ }^{+}$occurs through an anoxic pathway.

Anoxic oxidation of $\mathrm{NH}_{4}{ }^{+}$and the reduction of $\mathrm{FeOOH}$ simultaneously make the conventional nitrification process faster [17]. The presence of $\mathrm{NO}_{3}{ }^{-}$and $\mathrm{NO}_{2}{ }^{-}$could be due to the conversion of $\mathrm{NH}_{4}{ }^{+}$into $\mathrm{NO}_{3}{ }^{-}, \mathrm{NO}_{2}{ }^{-}$as $\mathrm{FeOOH}$ reduces (Figs.1 (a) and (b)). This process's main advantage is that denitrification coupled to the oxidation of $\mathrm{Fe}^{2+}$ to $\mathrm{Fe}^{3+}$ can occur, thereby regenerating $\mathrm{FeOOH}$ and reducing $\mathrm{NO}_{3}{ }^{-}$and $\mathrm{NO}_{2}^{-}$to $\mathrm{N}_{2}$ gas. The recycling of $\mathrm{FeOOH}$ sustains the removal of $\mathrm{NH}_{4}{ }^{+}$and thus, the process becomes economical. From Fg.1(c) and (d), it is evident that the removal of $\mathrm{NH}_{4}{ }^{+}$ increases as cycles progress. The fluctuations in the removal rate can be attributed to the hydrolysis of sludge due to nonadaptive biomass. Lysis of cells can result in the release of organic nitrogen, which breaks down to form $\mathrm{NH}_{4}{ }^{+}$, thereby showing an increase in the concentration of $\mathrm{NH}_{4}{ }^{+}$and COD also increases correspondingly [24-25]. The presence of residual COD and occasional increase in the observed value (Fig.1 (e)) could be because of the lysis of biomass that failed to acclimatize to the experimental conditions.

On comparing the removal rate of $\mathrm{NH}_{4}{ }^{+}$for the different sludges used, biomass enriched from anaerobic sludge showed a better removal rate when the cycle time was 3 days. As the cycle time was reduced to 1 day, the removal of ammonium showed better results than 3 days with culture enriched using anaerobic sludge showing more reduction than aerobic sludge. This could be attributed to the presence of acclimatized microbes to $\mathrm{Fe}$ and $\mathrm{NH}_{4}{ }^{+}$during the anaerobic sludge digestion process. Therefore, these results substantiate the microbially mediated removal of ammonium in an anoxic environment with the aid of $\mathrm{FeOOH}$ as the electron acceptor. 


\section{IV.FIGURES}

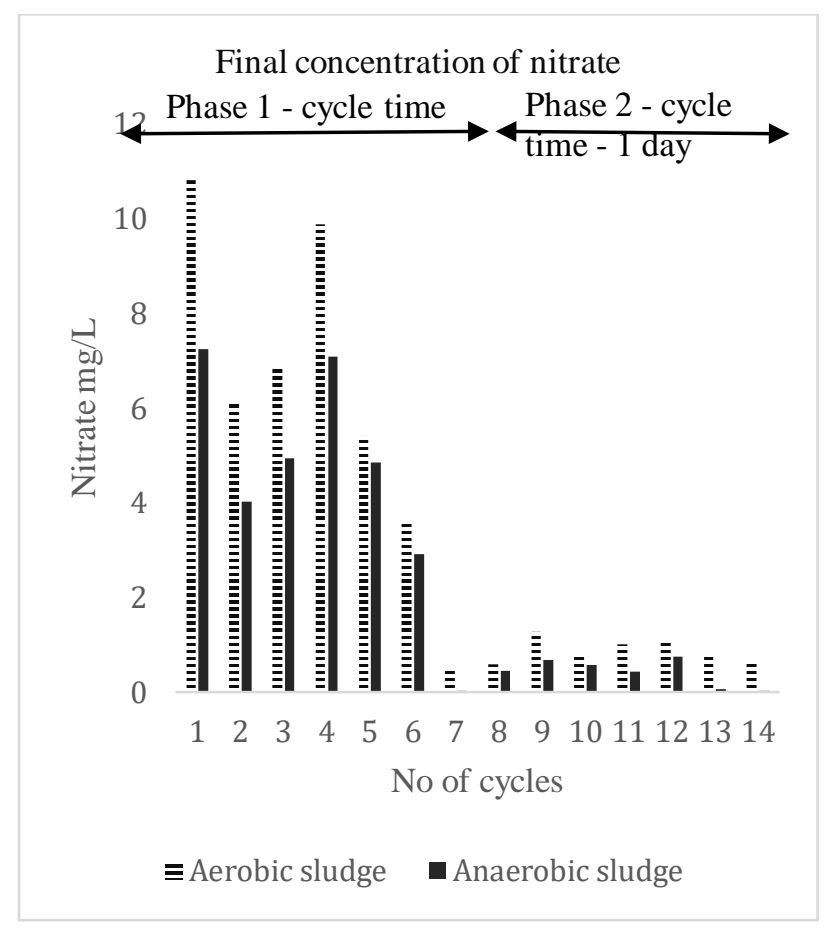

(a)

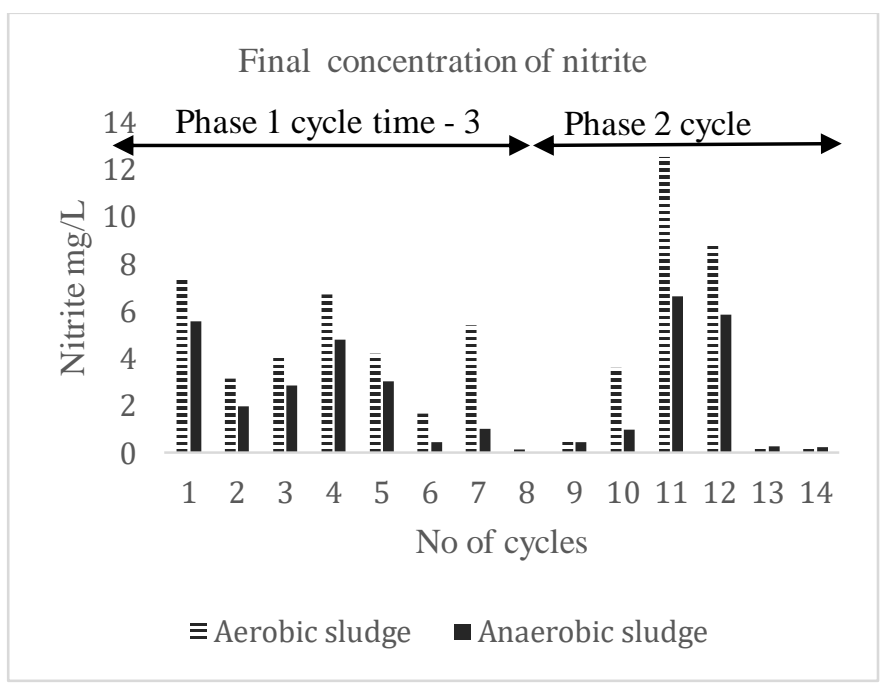

(b)

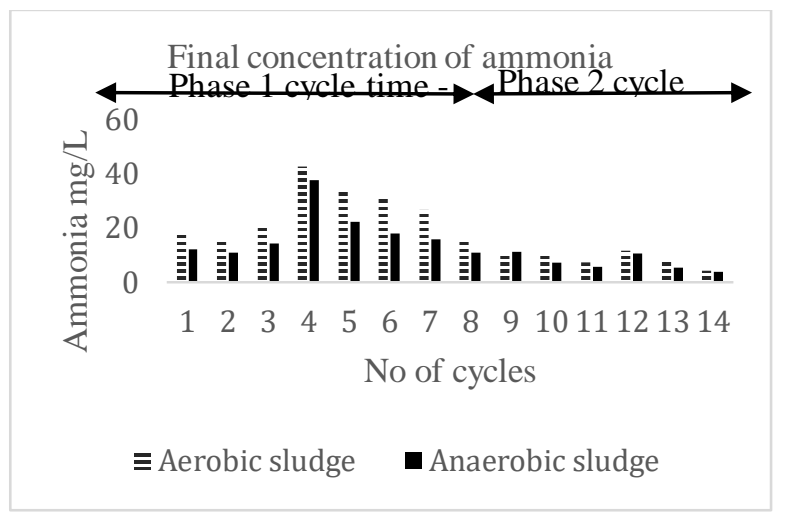

(c)

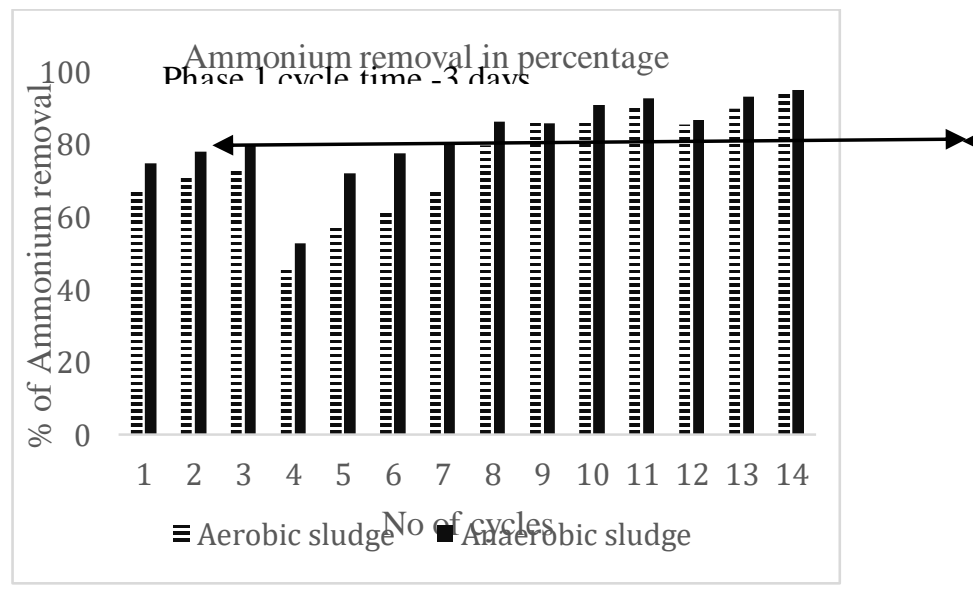

(d)

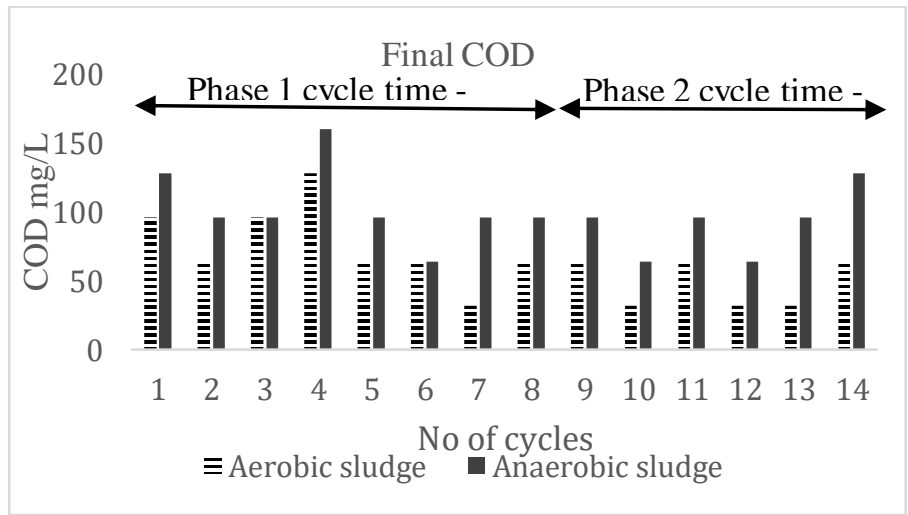

(e)

Fig.1.The performance profile for enrichment studies (Phase I from cycle 1 to 8 -cycle time of 3 days ; Phase II from cycle 9 to 14-cycle time of 1 day)

(a) Profile of nitrate of the effluent; (b) Profile of nitrite of the effluent; (c) Profile of ammonium of the effluent; (d) 
Profile of Percentage of removal of ammonium from the reactors (e) Profile of COD of the effluent

\section{CONCLUSION}

This study reveals that GNOF acts as an electron acceptor for the anoxic removal of $\mathrm{NH}_{4}{ }^{+}$through a process mediated by microbes. Sludge from different eco-systems can serve as potential seed biomass for enriching culture to facilitate $\mathrm{NH}_{4}{ }^{+}$removal in SBR with a cycle time of 1 day. However, biomass from anaerobic conditions showed better removal than that from aerobic conditions consistently in many cycles. Removal of $\mathrm{NH}_{4}{ }^{+}$coupled with the recycling of $\mathrm{Fe}$ prevents the accumulation of $\mathrm{NO}_{3}{ }^{-}$and $\mathrm{NO}_{2}^{-}$making the process economical and sustainable. This process becomes a useful option as it requires no addition of COD or alkalinity.

\section{REFERENCES}

1. Jetten, M. S., Wagner, M., Fuerst, J., van Loosdrecht, M., Kuenen, G., \& Strous, M. (2001). Microbiology and application of the anaerobic ammonium oxidation ('anammox') process. Current opinion in biotechnology, 12(3), 283-288.

2. Strous, M., Fuerst, J. A., Kramer, E. H., Logemann, S., Muyzer, G., Van de Pas-Schoonen, K. T., ... \& Jetten, M. S. (1999). Missing lithotroph identified as new planctomycete. Nature, 400(6743), 446-449.

3. Shuai, W., \& Jaffé, P. R. (2019). Anaerobic ammonium oxidation coupled to iron reduction in constructed wetland mesocosms. Science of the total environment, 648, 984-992.

4. Stein, L. Y., La Duc, M. T., Grundl, T. J., \& Nealson, K. H. (2001). Bacterial and archaeal populations associated with freshwater ferromanganous micronodules and sediments. Environmental microbiology, 3(1), 10-18.

5. Cummings, D. E., March, A. W., Bostick, B., Spring, S., Caccavo, F., Fendorf, S., \& Rosenzweig, R. F. (2000). Evidence for microbial Fe (III) reduction in anoxic, miningimpacted lake sediments (Lake Coeur d'Alene, Idaho). Applied and Environmental Microbiology, 66(1), 154162.

6. Nielsen, J. L., Juretschko, S., Wagner, M., \& Nielsen, P. H. (2002). Abundance and phylogenetic affiliation of iron reducers in activated sludge as assessed by fluorescence in situ hybridization and microautoradiography. Applied and Environmental Microbiology, 68(9), 4629-4636.

7. Lovley, D. R. (1993). Dissimilatory metal reduction: Annual Reviews in Microbiology, v. 47.

8. Park, H. S., Kim, B. H., Kim, H. S., Kim, H. J., Kim, G. T., Kim, M., ... \& Chang, H. I. (2001). A novel electrochemically active and $\mathrm{Fe}$ (III)-reducing bacterium phylogenetically

Vol. 4 (5), November 2020, www.ijirase.com related to Clostridium butyricum isolated from a microbial fuel cell. Anaerobe, 7(6), 297-306.

9. Wang, Y., Xu, L., Wang, S., Ye, F., \& Zhu, G. (2019). Global distribution of anaerobic ammonia 1 oxidation (anammox) bacteria-field surveys in wetland, dryland, groundwater aquifer and snow. Frontiers in Microbiology, 10, 2583.

10. Lovley, D. R. (2000). Fe (III) and Mn (IV) reduction. In Environmental microbe-metal interactions (pp. 3-30). American Society of Microbiology.

11. Yang, W. H., Weber, K. A., \& Silver, W. L. (2012). Nitrogen loss from soil through anaerobic ammonium oxidation coupled to iron reduction. Nature Geoscience, 5(8), 538-541.

12. Burke, I. T., Boothman, C., Lloyd, J. R., Livens, F. R., Charnock, J. M., McBeth, J. M., ... \& Morris, K. (2006). Reoxidation behavior of technetium, iron, and sulfur in estuarine sediments. Environmental science \& technology, 40(11), 3529-3535.

13. Viet, T. N., Behera, S. K., Kim, J. W., \& Park, H. S. (2008). Effects of oxidation reduction potential and organic compounds on anammox reaction in batch cultures. Environmental Engineering Research, 13(4), 210215.

14. Ruby, C., Upadhyay, C., Géhin, A., Ona-Nguema, G., \& GÉnin, J. M. R. (2006). In situ redox flexibility of FeII-III oxyhydroxycarbonate green rust and fougerite. Environmental science \& technology, 40(15), 4696-4702.

15. Liu, S., \& Horn, H. (2012). Effects of Fe (II) and Fe (III) on the single-stage deammonification process treating highstrength reject water from sludge dewatering. Bioresource technology, 114, 12-19.

16. Swathi, D., Sabumon, P. C., \& Maliyekkal, S. M. (2018). Anoxic ammonia removal using granulated nanoscale oxyhydroxides of $\mathrm{Fe}$ (GNOF) in a SBR. Journal of environmental chemical engineering, 6(4), 4273-4281.

17. Van der Star, W. R., Abma, W. R., Blommers, D., Mulder, J. W., Tokutomi, T., Strous, M., ... \& van Loosdrecht, M. C. (2007). Startup of reactors for anoxic ammonium oxidation: experiences from the first full-scale anammox reactor in Rotterdam. Water research, 41(18), 4149-4163.

18. Imajo, U., Tokutomi, T., \& Furukawa, K. (2004). Granulation of Anammox microorganisms in up-flow reactors. Water Science and Technology, 49(5-6), 155-164.

19. Bae, H., Park, K. S., Chung, Y. C., \& Jung, J. Y. (2010). Distribution of anammox bacteria in domestic WWTPs and their enrichments evaluated by real-time quantitative PCR. Process Biochemistry, 45(3), 323-334.

20. Date, Y., Isaka, K., Ikuta, H., Sumino, T., Kaneko, N., Yoshie, S., ... \& Inamori, Y. (2009). Microbial diversity of anammox bacteria enriched from different types of seed sludge in an anaerobic continuous-feeding cultivation reactor. Journal of bioscience and bioengineering, 107(3), 281-286

21. Sabumon, P. C. (2007). Anaerobic ammonia removal in presence of organic matter: a novel route. Journal of Hazardous Materials, 149(1), 49-59.

22. American Public Health Association, American Water Works 
Association, Water Pollution Control Federation, \& Water Environment Federation. (1915). Standard methods for the examination of water and wastewater (Vol. 2). American Public Health Association..

23. Bae, H., Park, K. S., Chung, Y. C., \& Jung, J. Y. (2010). Distribution of anammox bacteria in domestic WWTPs and their enrichments evaluated by real-time quantitative PCR. Process Biochemistry, 45(3), 323-334.

24. Wang, T., Zhang, H., Yang, F., Li, Y., \& Zhang, G. (2013). Start-up and long-term operation of the Anammox process in a fixed bed reactor (FBR) filled with novel non-woven ring carriers. Chemosphere, 91(5), 669-675.

\section{Acknowledgements}

We gratefully acknowledge Department of Science and Technology (DST), Government of India, for supporting this work through the research grant DST/TM/WTI/WIC/2K17/82/(G).

First three authors are final year Civil Engineering students and have contributed towards the research work presented in this paper as a part of their capstone project. The corresponding author is a Professor (Higher Academic Grade) in Civil Engineering and currently holding the post of Dean, Sponsored Research \& Industrial Consultancy at VIT, Chennai. He has 28 years of experience in the Environmental Engineering field out of which 10 years in $R \& D$ and Consultancy services. He obtained his $\mathrm{PhD}$ in Environmental Engineering from IIT Madras, and a Masters (M.Tech) in Environmental Engineering from IIT Kanpur, India. $\mathrm{He}$ is a fellow of Institution of Engineers (FIE), India, and a recipient of the GE Ecomagination Excellence Award for the best $\mathrm{PhD}$ thesis from IIT, Madras. He is also a recipient of the best teacher awards from VIT, Vellore (2004) and Lions Clubs International, Chennai (2014) and best paper awards at international conferences. His research interests are in sustainable waste treatment and management of both solids and liquids especially by employing biological processes. He has published more than 125 papers in international journals and conferences. $\mathrm{He}$ is a reviewer for many international journals published by Elsevier. He has executed $10 \mathrm{R} \& \mathrm{D}$ projects successfully funded from both government and private agencies. 